\title{
Carbon nanotubes-based sensor for ammonia gas detection - an overview
}

\author{
N.M. Nurazzi ${ }^{1)}$ (ORCID ID: 0000-0001-7697-0511), S.Z.N. Demon ${ }^{1)}$ (0000-0001-6706-7216), N.A. Halim ${ }^{1)}$ (0000-0001-8077-824X), \\ I.S. Mohamad ${ }^{2)}$ (0000-0002-3805-9919), N. Abdullah ${ }^{1), ~ *)}$ (0000-0002-8519-3379)
}

DOI: dx.doi.org/10.14314/polimery.2021.3.3

\begin{abstract}
A sensitive, selective and reliable sensing techniques for ammonia $\left(\mathrm{NH}_{3}\right)$ gas detection have been highly demanded since $\mathrm{NH}_{3}$ is both a commonly utilized gas in various industrial sectors, and considered as a toxic and caustic agent that can threat human health and environment at a certain level of concentrations. In this article, a brief on the fundamental working principles of sensor specifications of the analytes detection techniques relying has been reviewed. Furthermore, the mechanism of $\mathrm{NH}_{3}$ detection and recent progress in the development of advanced carbon nanotubes (CNTs)-based $\mathrm{NH}_{3}$ gas sensors, and their performance towards the hybridization with the conductive polymers was comprehensively reviewed and summarized. Finally, the future outlook for the development of highperformance $\mathrm{NH}_{3}$ sensors was presented in the conclusions part.
\end{abstract}

Keywords: ammonia, carbon nanotubes, chemical sensor, conductive polymer, nanocomposite.

\section{Czujniki na bazie nanorurek węglowych do wykrywania obecności amoniaku - przegląd literatury}

Streszczenie: Amoniak $\left(\mathrm{NH}_{3}\right)$ to gaz powszechnie stosowany w różnych sektorach przemysłu, jest toksyczny i żrący, a powyżej określonego poziomu stężeń może zagrozić ludzkiemu zdrowiu i środowisku, dlatego ciągle trwają poszukiwania czułych, selektywnych i niezawodnych metod wykrywania gazów amoniakalnych. W niniejszym artykule dokonano przeglądu specyfikacji i podstawowych zasad działania czujników stosowanych w technikach wykrywania takich analitów. Szczegółowo przeanalizowano też mechanizm wykrywania i niedawny postęp w opracowywaniu zaawansowanych czujników do wykrywania gazu $\mathrm{NH}_{3^{\prime}}$ opartych na nanorurkach węglowych (CNTs), a także ich modyfikacje obejmujące hybrydyzację z polimerami przewodzącymi. Przedstawiono również perspektywy rozwoju wysoko wydajnych czujników $\mathrm{NH}_{3}$.

Słowa kluczowe: amoniak, nanorurki węglowe, czujnik chemiczny, polimer przewodzący, nanokompozyt.

In recent decades, novel gas sensors have been developed and used in different fields such as environmental analysis [1], electrical and electronic devices [2], automotive industry [3], medical applications [4] and air quality control indoors [5]. Especially, there has been an increasing need for monitoring hazardous gases including carbon monoxide $(\mathrm{CO})$, carbon dioxide $\left(\mathrm{CO}_{2}\right)$, (nitrous oxide $\left./ \mathrm{NO}_{\mathrm{x}}\right)(\mathrm{x}=0.5,1$, and 2$)$, (sulfur oxide $/ \mathrm{SO}_{\mathrm{x}}$ ) $(x=2$ and 3$)$, and $\mathrm{NH}_{3}$ as concerns over environment and

\footnotetext{
1) National Defence University of Malaysia, Centre for Defence Foundation Studies, Kem Sungai Besi, 57000 Kuala Lumpur, Malaysia.

2) Universiti Teknikal Malaysia Melaka, Faculty of Mechanical Engineering, Hang Tuah Jaya, 76100 Durian Tunggal, Melaka, Malaysia.

*) Author for correspondence: norli.abdullah@upnm.edu.my
}

human health. $\mathrm{NH}_{3}$ gas detection has attracted significant attention in the field of gas sensors among these hazardous gases, which is important because $\mathrm{NH}_{3}$ is one of

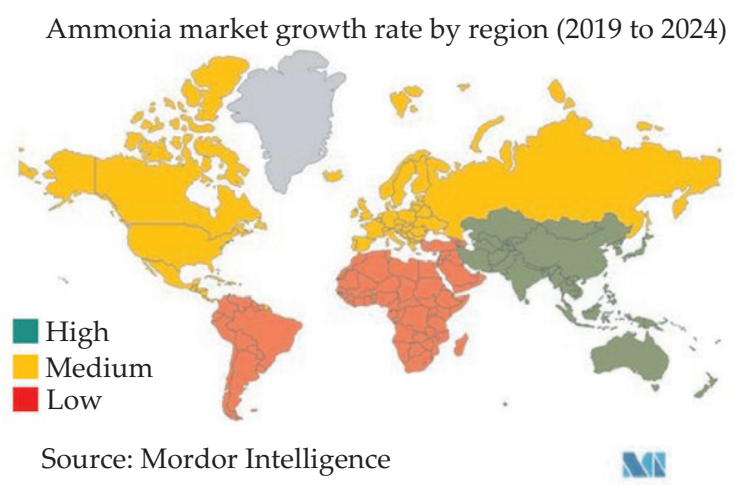

Fig. 1. $\mathrm{NH}_{3}$ market growth rate by region for 2019 and forecasted to 2024; reproduced from ref. [10], Mordor Intelligence 
the most common chemicals manufactured and applied in diverse regions around the world [6-9]. Referring to Mordor Intelligence for the $\mathrm{NH}_{3}$ market growth, trends, and forecast (2020 to 2025) (Fig. 1), the agriculture industry dominates the global $\mathrm{NH}_{3}$ market, with an estimated market share of more than $80 \%$, and the rest of $20 \%$ has been manufactured for textiles, mining, pharmaceuticals, and refrigeration etc. Interestingly, the $\mathrm{NH}_{3}$ market was dominated by Asia Pacific [10].

The production of $\mathrm{NH}_{3}$ follows Haber-Bosch process [Eq. (1)] which employs the reaction between hydrogen and nitrogen with an iron-based catalyst under high temperatures $\left(\sim 500^{\circ} \mathrm{C}\right)$ and high pressures $(\sim 30 \mathrm{MPa})$ [11]. In addition, since $\mathrm{NH}_{3}$ is a great source of hydrogen $(\mathrm{H})$, it is often utilized in automobiles, specifically for diesel engines to reduce harmful $\mathrm{NO}_{x}$ gases by selective catalytic reduction (SCR) as shown in the following reducing reaction in Eq. (2) [12]. Other organic wastes containing nitrogen, such as protein, urea, and amino acid, are converted to $\mathrm{NH}_{3}$ by anaerobic digestion. This leads to accumulation of certain concentrations of $\mathrm{NH}_{3}$ in the long term.

$$
\begin{gathered}
3 \mathrm{H}_{2}+\mathrm{N}_{2} \rightarrow 2 \mathrm{NH}_{3} \\
\Delta H_{300}=46.35 \mathrm{KJ} / \mathrm{mol}, \Delta S_{300}=99.35 \mathrm{~J} / \mathrm{Kmol} \\
4 \mathrm{NO}+4 \mathrm{NH}_{3}+\mathrm{O}_{2} \rightarrow 4 \mathrm{~N}_{2}+6 \mathrm{H}_{2} \mathrm{O}
\end{gathered}
$$

The specific gravity of $\mathrm{NH}_{3}$ gas is 0.588 and specific gravity of the liquid is 0.619 , whereas, the value of specific gravities of gaseous and liquid $\mathrm{NH}_{3}$ are relatively equal to air and water, respectively. The liquid $\mathrm{NH}_{3}$ will expand by 850 times when evaporating and the anhydrous $\mathrm{NH}_{3}$ gas is considerably lighter than air, and will rise in dry air. However, because of $\mathrm{NH}_{3}$ 's tremendous affinity for water, it reacts immediately with the humidity in the air and may remain close to the ground. In the atmosphere, the typical $\mathrm{NH}_{3}$ level is in low as part per billion (ppb), which is 1 to $5 \mathrm{ppb}$ levels [13]; though, inhaling more than the safe level of $\mathrm{NH}_{3}$ can cause life-threatening illnesses due to its highly toxic and caustic properties to the skin, eyes, and lungs. According to the Department of Occupational Safety and Health Malaysia (DOSH), $\mathrm{NH}_{3}$ is a gas with a distinctive pungent odour which can normally be detected by smell at concentrations as low as 5 parts per million (ppm). While, the permissible exposure limit (PEL) is $25 \mathrm{ppm}$ or $17 \mathrm{mg} / \mathrm{m}^{3}$ for eight-hour time weighted average airborne concentration.

Hence, the detection of $\mathrm{NH}_{3}$ is important in terms of both environmental as well as for health safety. Actually, there are available instruments of $\mathrm{NH}_{3}$ detection, such as gas chromatograph (GC) and the traditional ceramics tube or inter-finger probe-based gas sensing devices. However, relative portability, real-time sensing, low cost, transparency and versatility are the drawbacks to be concerned [12]. They cannot therefore meet the growing demand for flexible gas sensors together with the desired advantages in the future. Recently, extensive interest in improving reliable $\mathrm{NH}_{3}$ gas sensors have been rising as innumerable fields employing $\mathrm{NH}_{3}$ gas sensors has been expanding. There are a vast number of gas sensors available to control and detect the $\mathrm{NH}_{3^{\prime}}$ which vary in their concentration ranges, effectiveness and their sensing mechanisms. A wide variety of materials, such as metal oxides $\left(\mathrm{SnO}_{2}, \mathrm{TiO}_{2}, \mathrm{~V}_{2} \mathrm{O}_{5}\right.$, etc. $)$ [14], graphene [15], CNTs $[16,17]$, conductive polymers [polyaniline (PANI), polypyrrole (PPy), polythiophene (PTh), etc.], functionalized CNTs [18-21], and hybridization of functionalized CNTs with the conductive polymers either by covalent or noncovalent functionalization [22] have been used as sensing materials for various $\mathrm{NH}_{3}$ gas sensor applications.

Briefly, CNT including single-wall carbon nanotubes (SWCNTs) and multiwall carbon nanotubes (MWCNTs) play a big role in gas sensing enhancements. This is due to their distinct electrical and mechanical properties as well as ability to change the electrical properties, such as resistivity under gas adsorption. Figure 2 shows the schematic diagram of $\mathrm{NH}_{3}$ adsorption on CNT with StoneWales defect with pre-dissociated oxygen atoms on fabricated sensor [23]. Adsorption of $\mathrm{NH}_{3}$ is comprised of several configurations which are direct adsorption of $\mathrm{NH}_{3}$ to the CNTs in the middle of the structure, chemisorption of $\mathrm{NH}_{3}$ to $\mathrm{CNT}$ within metal-CNTs contact and chemisorption of $\mathrm{NH}_{3}$ to the metal electrode.

However, metal-oxide-based sensors operate efficiently at high operating temperatures typically in the

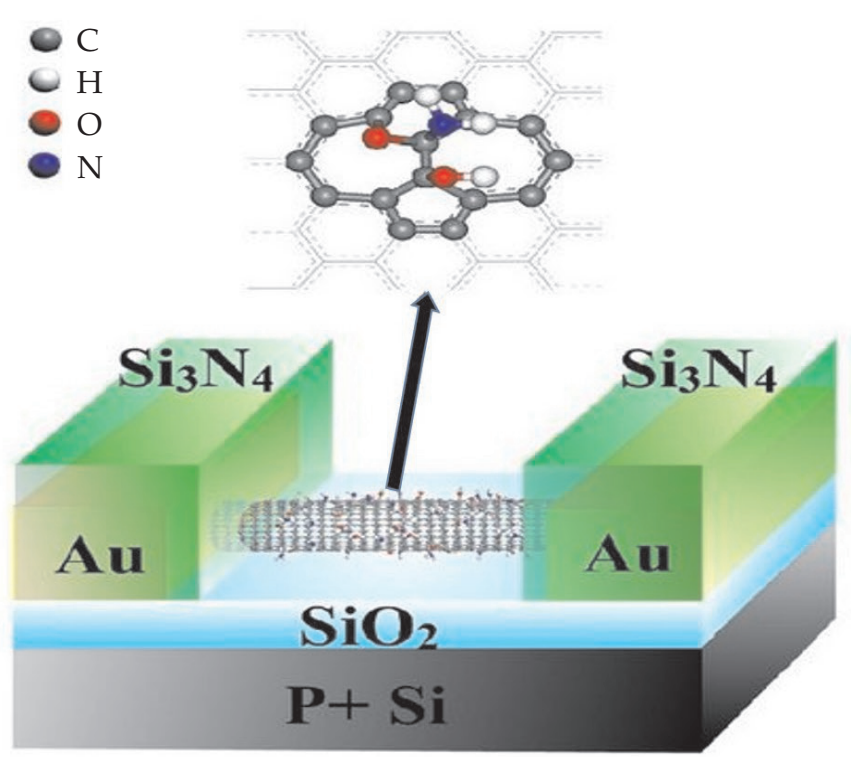

Fig. 2. Schematic diagram of $\mathrm{NH}_{3}$ adsorption on $\mathrm{CNT}$ with Stone-Wales defect with pre-dissociated oxygen atoms on fabricated sensor; reproduced from ref [23], IntechOpen 
200 to $500^{\circ} \mathrm{C}$ range, which generally lead to high power consumption and have thus by far hindered their practical use in many applications [24]. Hence, severe research has been devoted to the development of room temperature operatable gas sensors. In this aspect, CNT have been found to be an ideal candidates, and gained considerable interest owing to their unique physical and chemical properties, high aspect ratio, excellent chemical and environmental stability [25]. Recent studies demonstrate MWCNTs as one of the ideal materials for detection of a wide variety of oxidizing/reducing gases, such as, $\mathrm{NO}_{2}$ $\mathrm{H}_{2} \mathrm{~S}, \mathrm{NH}_{3}$, etc., under ambient conditions [26]. Sensing mechanism of MWCNTs-based sensors upon exposure to gas molecules mainly depends on the changes in their electrical properties due to charge transfer between MWCNTs and the gas molecules. Despite many attractive properties of MWCNTs, it has been reported [27, 28] that their low sensitivity, lack of selectivity, very long regeneration time and poor interaction with gas molecules limit their commercial applications as sensors. Various researches have been made to overcome and improve this problem, and researchers have identified that functionalization of MWCNTs with various metallic/conducting polymers can significantly improve their sensor performance [29].

Other research on CNTs/polymer nanocomposites have revealed that the combination of MWCNT and polymer in the composite material could broaden the application range of the individual materials. This will be discussed in the following section. The findings have recently shown that the modifications by conductive polymers enhanced the sensing properties of MWCNTs as well as the mechanical properties of polymers [30, 31]. Significant improvements in the gas sensing performance have been achieved in these nanocomposites for various gases compared to their individual components. Such nanocomposites demonstrated excellent sensor performance at room temperature, leading to very low energy consumption and therefore lower operating costs, as well as to simpler fabrication of sensor devices.

In light of this, in this review the development of CNTs-based sensors for $\mathrm{NH}_{3}$ detection have been discussed. This includes the specifications of response towards the analytes detection, and at the last part on recent development of CNTs-based sensors for $\mathrm{NH}_{3}$ gas detection from 2015 to 2020. The summary for the CNTs-based sensor together with the sensor response specifications are summarized in Table 2 (see in following section).

\section{CARBON NANOTUBES BASED GAS SENSOR WORKING PRINCIPLE}

Gas sensor is a device used to detect and provide a measurement of the concentration of some interest analytes which interprets the presence of the analytes within surroundings. Generally, electrically-transduced CNT-based gas sensor comprises of two paramount compartments

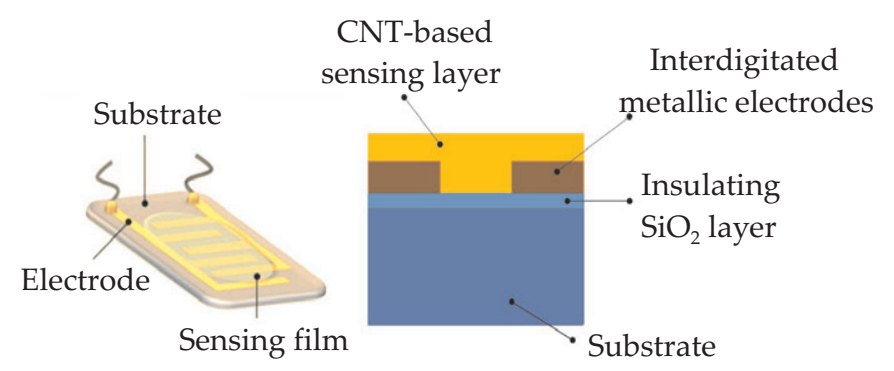

Fig. 3. Schematic illustration of interdigitated gas sensing device; reproduced from ref. [32]

which are the sensing material (CNT-based sensing layer) and the transducer (interdigitated chemiresistive gas sensor) as displayed from Fig. 3.

Whereas, CNT-based sensing film shows high sensitivity towards such gases as $\mathrm{NH}_{3}, \mathrm{NO}_{2}, \mathrm{CO}, \mathrm{SO}_{2}, \mathrm{H}_{2} \mathrm{~S}$ and other VOCs. According to Singh and Bonne, the concentration of the analytes adsorbed at the active materials of the sensor produces a significant change towards the physical properties of the sensing material including electrical resistance, conductivity $(\sigma)$, work function $(\phi)$ and permittivity $(\varepsilon)$ [33]. Increasing or decreasing of aforementioned properties can be measured as output data displayed as electrical signal such as current $(I)$ or voltage $(V)$ which then will be interpreted into sensor response $(R)$ which defined as $R=100 \cdot\left[\left(R_{t}-R_{0}\right) / R_{0}\right]$, where $R_{0}$ and $R_{\mathrm{t}}$ are the resistance at initial and after exposure to analyte, for chemiresistive-type sensor.

The response is contributed by the p-type conductivity in semiconducting CNTs due to electrical charge transfer. Analyte molecules of $\mathrm{NH}_{3}$ exposed to the active layer were adsorbed onto the CNT surface inducing electron transfer as well as changing the electrical conductivity and resistivity of the material [34]. This is due to the fact that transferred electrons recombine with charge carrier holes, thus, decreasing the concentration of charge carrier and lead to increasing electrical resistance. The mechanism works reversely for $\mathrm{NO}_{2}$ exposure [35]. Figure 4 displays the polar nature of the CNT surface interacting with analyte molecules including electron donor $\left(\mathrm{NH}_{3}\right)$

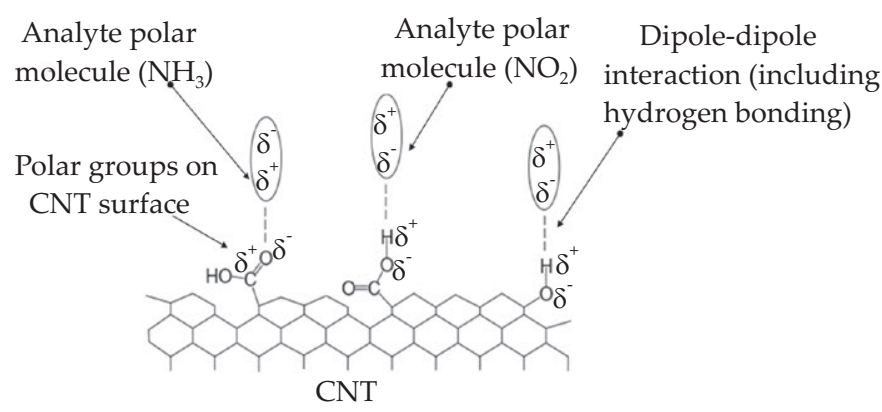

Fig. 4. Mechanism of gas sensing operating on p-type CNT with reducing and oxidizing type gases; reproduced from ref. [35]

or acceptor $\left(\mathrm{NO}_{2}\right)$. 
$\mathrm{T}$ a b 1 e 1 . Sensing response behavior of $p$-type and $n$-type sensors to reducing and oxidizing analytes

\begin{tabular}{l|c|c|c}
\hline \multicolumn{1}{c|}{ Sensing response behavior } & Examples of analytes & p-type sensor & n-type sensor \\
\hline Reducing analytes & $\mathrm{CO}, \mathrm{NH}_{3^{\prime}} \mathrm{C}_{2} \mathrm{H}_{5} \mathrm{OH}$, etc. & Resistance increases & Resistance decreases \\
Oxidizing analytes & $\mathrm{NO}, \mathrm{NO}_{2^{\prime}} \mathrm{O}_{3^{\prime}}$ etc. & Resistance decreases & Resistance increases \\
Dominant charge carrier & - & Holes $\left(\mathrm{h}^{+}\right)$ & Electrons $\left(\mathrm{e}^{-}\right)$ \\
\hline
\end{tabular}

\section{SENSOR RESPONSE SPECIFICATIONS TOWARDS THE ANALYTES}

Sensor response traits of n-type and p-type gas sensors to different gases are summarized in Table 1 [36].

Because of these different characteristics, sensor response is defined according to resistivity of the active layer and it is defined in different ways depending on the type of measurements. Nevertheless, it is easily and commonly described as the ratio of resistance in air $\left(R_{\mathrm{a}}\right)$ to resistance in the presence of analyte $\left(R_{\mathrm{g}}\right)\left(R_{\mathrm{a}} / R_{\mathrm{g}}\right)$ for n-type material with a reducing analyte. The response is expressed in the other way $\left(R_{\mathrm{g}} / R_{\mathrm{a}}\right)$ for an n-type material with an oxidizing analyte $[37,38]$. It is vice versa for p-type sensors $[39,40]$. Although several compiled sensors make up a p-n heterojunction, they are decidedly sorted into their single dominant charge carrier trait of either n-type or p-type behavior-based on how resistivity decreases or increases in the augmentations of analyte concentration. This is to guarantee a straightforward understanding and an effective assessment of analyte sensing characteristics for both n-type and p-type gas sensors. Another study by Husain et al. (2020) on electrical conductivity an $\mathrm{NH}_{3}$ sensing studies on PTh/MWCNTs nanocomposites had measured the sensing response $(S)$ using the Eq. (3) [41]:

$$
S=\Delta \sigma / \sigma_{\mathrm{i}} \times 100
$$

where: $\sigma_{i}$ and $\Delta \sigma$ indicate initial direct current (DC) electrical conductivity and change in the DC electrical conductivity upon analytes detection for a specific time (s), respectively. Figure 5 shows the schematic diagram for n-type model of metal oxide semiconductor (MOS)

In normal air In oxidizing analytes In reducing analytes

\begin{tabular}{|c|c|c|}
\hline $\mathrm{O}^{-} \mathrm{O}^{-} \mathrm{O}^{-}$ & $\mathrm{NO}^{-} \mathrm{O}^{-} \mathrm{NO}^{-} \mathrm{O}^{-} \mathrm{NO}^{-} \mathrm{O}^{-}$ & $\mathrm{O}^{-}$ \\
\hline $0^{-} \quad 0^{-} \quad 0^{-}$ & $\mathrm{NO}^{-} \mathrm{O}^{-} \mathrm{NO}^{-} \mathrm{O}^{-} \mathrm{NO}^{-} \mathrm{O}^{-}$ & $\mathrm{O}^{-} \underset{\mathrm{CO}}{\mathrm{CO}_{2}}$ \\
\hline $\begin{array}{l}\text { Depletion layer } \\
\text { Semiconductor layer }\end{array}$ & Resistance & Resistance \\
\hline
\end{tabular}

Fig. 5. Schematic diagram for n-type model of MOS gas sensors in normal air, oxidizing analyte and reducing analytes; reproduced from ref. [42], Sensors gas sensors in normal air, oxidizing analyte and reducing analytes [42].

\section{Response temperature}

Response temperature is the temperature at which the sensor detects the analytes, and gives a signal at the sensor output. Many sensors can be operated at room temperature $[43,44]$, and some others give responses at an elevated temperature (an elevated temperature is defined as at least $100^{\circ} \mathrm{C}$ for liquids or $240^{\circ} \mathrm{C}$ for solids) $[45,46]$. For safety and environmental applications, sensors reacting to room temperature could be used to notify leaks or releases, such as installation in airports and schools etc., whereas those reacting at higher temperatures may find applications primarily for the monitoring of chemical reactions at elevated temperatures, such as in the factory, etc. Previous studies involving the use of CNTs-based conductive polymer gas sensors have shown promising results in terms of sensing response [47]. For instance, a hybrid of carboxylated MWCNT (MWCNT-COOH) wrapped poly(3,4-ethylenedioxythiophene) : poly(styrenesulfonate)(PEDOT : PSS) nanocomposites fabricated by inject printing exhibited the highest response of $1.56\left(R_{\mathrm{a}} / R_{\mathrm{g}}\right)$ toward $100 \mathrm{ppm}$ of $\mathrm{NO}_{2}$ at room temperature, with rapid response and recovery times. When comparing with the metal oxide-based sensors, the $\mathrm{ZnO}$ hollow spheres showed the highest sensor response of $286.8\left(R_{\mathrm{g}} / R_{\mathrm{a}}\right)$ toward 100 ppm of nitrogen oxide $\left(\mathrm{NO}_{2}\right)$ at $240^{\circ} \mathrm{C}$ [48]. Metal oxide gas sensors do show promising performance in gas sensing, but high operating temperature is their limitation in gas sensing application [49, 50]. High temperature raises the power consumption and reduces the sensor lifespan. Hence, a balance between operating temperature and sensor response should be attained for fabricating energy-efficient sensors [51-53].

\section{Response time}

Response time refers to the time needed by the gas sensor in its initial state to reach $90 \%$ of its stable value and start the alarm signal upon exposure to a particular gas [54]. Good gas sensing characteristics are achieved when the sensor's response time is short. The sensors exposed to high concentrations of experimental analytes should have a shorter response time than sensors exposed to low concentrations of gases, therefore the 
response times of sensors intended for safety purposes should be carefully regulated. The $\mathrm{CNTs}-$ based $\mathrm{NH}_{3}$ gas sensors described by researchers showed a wide range of response times from a few seconds to thousands of seconds. Other factors that positively influence response time are the flow of $\mathrm{NH}_{3}$ gas, the pressure of the gas, and the gas temperature [55].

\section{Recovery time}

Recovery time refers to the amount of time needed by a sensor for the signal to return to $90 \%$ of its initial state when the experimental gas flow is removed. Better sensor applications demand shorter sensor recovery times so that the sensor can be used several times. Factors that influenced the recovery times may depend on the concentration of the target gas, doping material, humidity and temperature, and particle size [56, 57].

\section{Sensitivity}

Sensitivity refers to the sensor's ability to detect the desired chemicals in the range of interest. In terms of the measurement, sensitivity of a gas sensor is defined as the ratio of the change in the electrical output in terms of voltage/resistance/conductance or frequency in the presence of the test gas mixed with air to the electrical output of the corresponding parameter [58]. For example, gas sensors-based on pristine CNTs have certain limitations, such as low sensitivity to some analytes. Defect free MWCNTs have a surface equivalent to graphite-possessing little adsorption affinity to most gases. Alternatively, if the adsorption energy is too high the sensor will have long recovery times or potentially suffer irreversibility. As an illustration, chemiresistors made with defective CNTs exhibit a greater sensitivity toward $\mathrm{NO}_{2}$ compared to defect-free sensors [59]. The observation is consistent with theoretical calculations indicating that the defect sites on the CNTs result in a strong chemisorption of $\mathrm{NO}_{2}$ and a large charge transfer interaction. In a similar way, MWCNTs chemically oxidized and full of defects can detect a few ppm of $\mathrm{NO}_{2}$ and $\mathrm{NH}_{3}$ while there is almost no response in pristine CNTs [60]. This dependence upon defects as adsorption sites creates both problems and opportunities [61]. Besides, the researchers agreed that nanostructures and small diameters could enhance sensor response by providing high surface-to volume ratios that enhanced the diffusion of gas molecules [62]. This also was proven by Chimowa et al. (2017) who have indicated that the sensitivity of the unfilled MWCNTsbased sensor was improved from 0.5 to $1.5 \%$ due to the metal oxide filling [63]. This is due to the high aspect ratio of nano MWCNTs and metal oxide that leads to an increase of interaction towards the analytes. Using theoretical density functional theory (DFT) electronic structure calculations, the enhanced response is due to the increased density of states around the Fermi level of the nanocomposite material as a result of the encapsulated metal oxide.

\section{RECENT CARBON NANOTUBES-BASED SENSORS PERFORMANCE (2015-2020)}

CNTs are considered as the strong candidates for their excellent properties. On the account of these exclusive properties and due to their unique and compact structure, the area of potential application of CNTs widely includes gas sensors (Table 2) [64-69]. However, due to some kind of modification in structural qualities, properties can be enhanced significantly in one way or the other. The density of CNTs can also affect the current density, the lesser the density of CNTs the higher the current density because there will be lesser the sensitivity effect (Table 2) [70]. In addition, gas sensing properties largely depend on CNTs defect sites and are surface phenomena. The higher the surface area, the larger will be the adsorption of target gas molecules and hence the sensing response will be higher. High quality CNT sensors with different orientations are being fabricated in order to detect $\mathrm{NH}_{3}$ and other pollutants gases like $\mathrm{CO}_{2}$, $\mathrm{NO}_{2}$, etc., at trace level concentration to monitor the environment properly [71,72]. Figure 6 shows the schematic diagram of SWCNT and MWCNT [73].

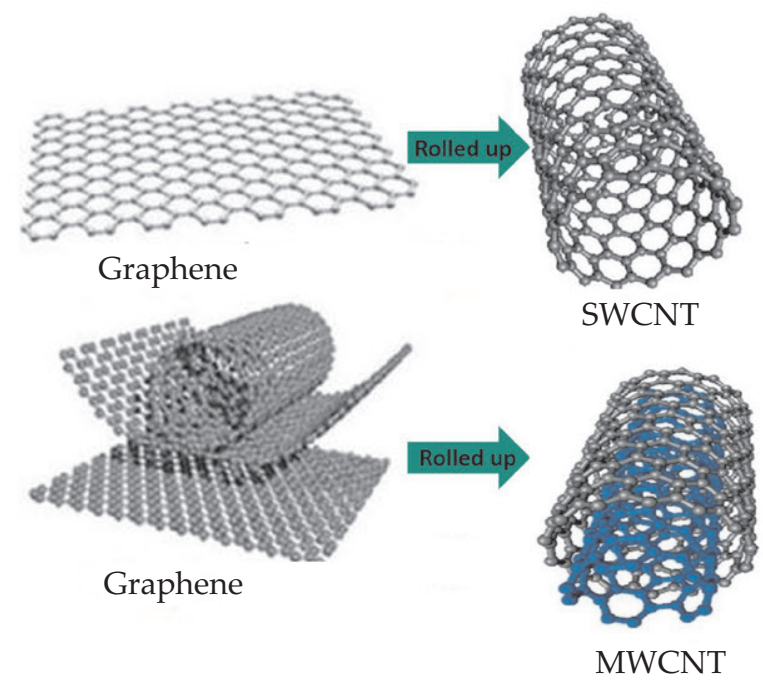

Fig. 6. Schematic diagram of SWCNT and MWCNT; reproduced from ref. [67], Frontiers in Systems Neuroscience

A single $4 \mu \mathrm{m}$ MWCNTs-OH network as a gas sensor for the detection of specific $\mathrm{NH}_{3}$ at room temperature was studied [74]. The sensitivities of the network were $1.3 \%$ at $14 \mathrm{ppm}, 3.3 \%$ at $27 \mathrm{ppm}$ and $6.13 \%$ at $68 \mathrm{ppm}$. The sensor is specifically considered to be sensitive to $\mathrm{NH}_{3}$ gas and does not affect the amount of ambient air. The MWCNT- $\mathrm{COOH}$ network gas sensor deposited on a polycarbonate (PC) membrane using vacuum filtration method was studied [75]. The MWCNT-COOH network was exposed to $\mathrm{NH}_{3}$ at two different concentrations; $19.2 \mathrm{ppm}$ and 
$\mathrm{T}$ a b l e 2. Comparison of CNT-based sensor with various sensor types for $\mathrm{NH}_{3}$ detection

\begin{tabular}{|c|c|c|c|c|c|c|c|c|}
\hline $\begin{array}{l}\text { Sensor } \\
\text { types }\end{array}$ & Selectivity & Sensitivity & $\begin{array}{l}\text { Operating } \\
\text { cost }\end{array}$ & $\begin{array}{l}\text { Operation } \\
\text { temperature }\end{array}$ & $\begin{array}{l}\text { Interest ana- } \\
\text { lyte }\end{array}$ & $\begin{array}{c}\text { Power } \\
\text { consumption }\end{array}$ & Application & Ref. \\
\hline CNT-based & High & High & Low & $\begin{array}{l}\text { Ambient } \\
\text { temperature }\end{array}$ & $\begin{array}{l}\text { VOCs and } \\
\mathrm{NH}_{3}\end{array}$ & Low & $\begin{array}{l}\text { Electrochemical } \\
\text { sensors, biosen- } \\
\text { sors and pres- } \\
\text { sure sensors for } \\
\text { medical equip- } \\
\text { ment, military } \\
\text { uses }\end{array}$ & [64] \\
\hline CP-based & Low & $\begin{array}{l}\text { Sensitive to } \\
\text { humidity } \\
\text { and temper- } \\
\text { ature, sensi- } \\
\text { tive to polar } \\
\text { compounds }\end{array}$ & $\begin{array}{l}\text { Low due to } \\
\text { wide range } \\
\text { of available } \\
\text { conducting } \\
\text { polymer }\end{array}$ & $\begin{array}{l}\text { Room tem- } \\
\text { perature }\end{array}$ & $\begin{array}{l}\text { VOCs, fast } \\
\text { response }\end{array}$ & Low & $\begin{array}{l}\text { Electrochemical } \\
\text { and biosensors } \\
\text { applications for } \\
\text { clinical diagno- } \\
\text { sis and surgical } \\
\text { interventions, } \\
\text { food industry } \\
\text { and thermal } \\
\text { sensors }\end{array}$ & [65] \\
\hline MOS & High & $\begin{array}{l}\text { High sen- } \\
\text { sitivity } \\
\text { towards } \\
\text { analytes } \\
\text { except } \\
\text { sulfur and } \\
\text { weak acid } \\
\text { gas, sen- } \\
\text { sitive to } \\
\text { humidity }\end{array}$ & $\begin{array}{l}\text { Low due to } \\
\text { easy to inte- } \\
\text { grate into } \\
\text { measure- } \\
\text { ment cir- } \\
\text { cuitry }\end{array}$ & $\begin{array}{l}\text { High tem- } \\
\text { perature }\end{array}$ & $\begin{array}{l}\text { Fast } \\
\text { response } \\
\text { and recov- } \\
\text { ery time } \\
\text { for low mol } \\
\text { wt \% com- } \\
\text { pounds }\end{array}$ & $\begin{array}{l}\text { High power } \\
\text { consumption }\end{array}$ & $\begin{array}{l}\text { Biosensors } \\
\text { application for } \\
\text { medical diag- } \\
\text { nosis-based on } \\
\text { human breath, } \\
\text { gas detection in } \\
\text { harsh environ- } \\
\text { ments }\end{array}$ & [66] \\
\hline Optical & $\begin{array}{l}\text { High due } \\
\text { to multi- } \\
\text { parameter } \\
\text { detection } \\
\text { capabilities }\end{array}$ & Very high & $\begin{array}{l}\text { High, com- } \\
\text { plex sensor- } \\
\text { array sys- } \\
\text { tems }\end{array}$ & $\begin{array}{l}\text { Low tem- } \\
\text { perature }\end{array}$ & & $\begin{array}{l}\text { High due to } \\
\text { delicate optics } \\
\text { and electrical } \\
\text { components }\end{array}$ & $\begin{array}{l}\text { Electro-optical } \\
\text { sensors for } \\
\text { electronic uses, } \\
\text { optical biosen- } \\
\text { sors, mili- } \\
\text { tary and law } \\
\text { enforcement, } \\
\text { biometrics }\end{array}$ & [67] \\
\hline MOSFET & Low & $\begin{array}{l}\text { Low sensi- } \\
\text { tivity to } \mathrm{NH}_{3} \\
\text { and } \mathrm{CO}_{2}\end{array}$ & $\begin{array}{l}\text { Low, high } \\
\text { mobility }\end{array}$ & - & - & $\begin{array}{l}\text { High due to } \\
\text { baseline drift } \\
\text { and require } \\
\text { environmen- } \\
\text { tal control }\end{array}$ & Biosensors & [68] \\
\hline SAW & $\begin{array}{l}\text { High as } \\
\text { specificity } \\
\text { to analyte } \\
\text { groups } \\
\text { affected by } \\
\text { polymeric } \\
\text { film sensor } \\
\text { coating }\end{array}$ & $\begin{array}{l}\text { High yet } \\
\text { sensitive to } \\
\text { temperature }\end{array}$ & $\begin{array}{l}\text { Low, high } \\
\text { mobility }\end{array}$ & $\begin{array}{l}\text { Ambient } \\
\text { temperature }\end{array}$ & $\begin{array}{l}\text { Good } \\
\text { response } \\
\text { time }\end{array}$ & $\begin{array}{l}\text { High due to } \\
\text { complex cir- } \\
\text { cuitry and } \\
\text { diverse sensor } \\
\text { coatings }\end{array}$ & $\begin{array}{l}\text { Biomolecules } \\
\text { sensors, drug } \\
\text { screens, diag- } \\
\text { nosis, envi- } \\
\text { ronmental } \\
\text { monitoring for } \\
\text { medical uses, } \\
\text { microbalances } \\
\text { and surface } \\
\text { acoustic-wave } \\
\text { (SAW) devices } \\
\text { for mechanical } \\
\text { applications }\end{array}$ & [69] \\
\hline
\end{tabular}

* MOS - metal-oxide-semiconductor, MOSFET - catalytic field-effect, SAW - surface acoustic wave

231.4 ppm, and the results show high sensitivity at $23.4 \%$ when exposed to $231.4 \mathrm{ppm}$ of $\mathrm{NH}_{3}$ and low sensitivity at $4.39 \%$ for 19.2 ppm $\mathrm{NH}_{3}$ exposure.

Another hybrid of SWCNT with metal oxide has been studied [76]. The high sensitivity gas sensing functionalizing from SWCNTs with tin(IV) oxide $\left(\mathrm{SnO}_{2}\right)$ for the $\mathrm{NH}_{3}$ gas detection shows the sensitivity of SWCNTs $/ \mathrm{SnO}_{2}$ nano- composite higher than the pristine SWCNTs. SWCNTs with $0.1 \mathrm{mg}$ of $\mathrm{SnO}_{2}$ gave the maximum improvement of 1.6 to $8.5 \%(4.5 \%, 3.9 \%, 1.0 \%)$ times in response in the concentration range of 0.5 to $100 \mathrm{ppm}$ for $\mathrm{NH}_{3}$ as compared to pristine SWCNTs (1.79\%). The synergistic enhancement of $\mathrm{NH}_{3}$ gas-sensing properties at low temperature by compositing $\mathrm{CNTs}$ with tungsten oxide $\left(\mathrm{WO}_{3}\right)$ nano- 


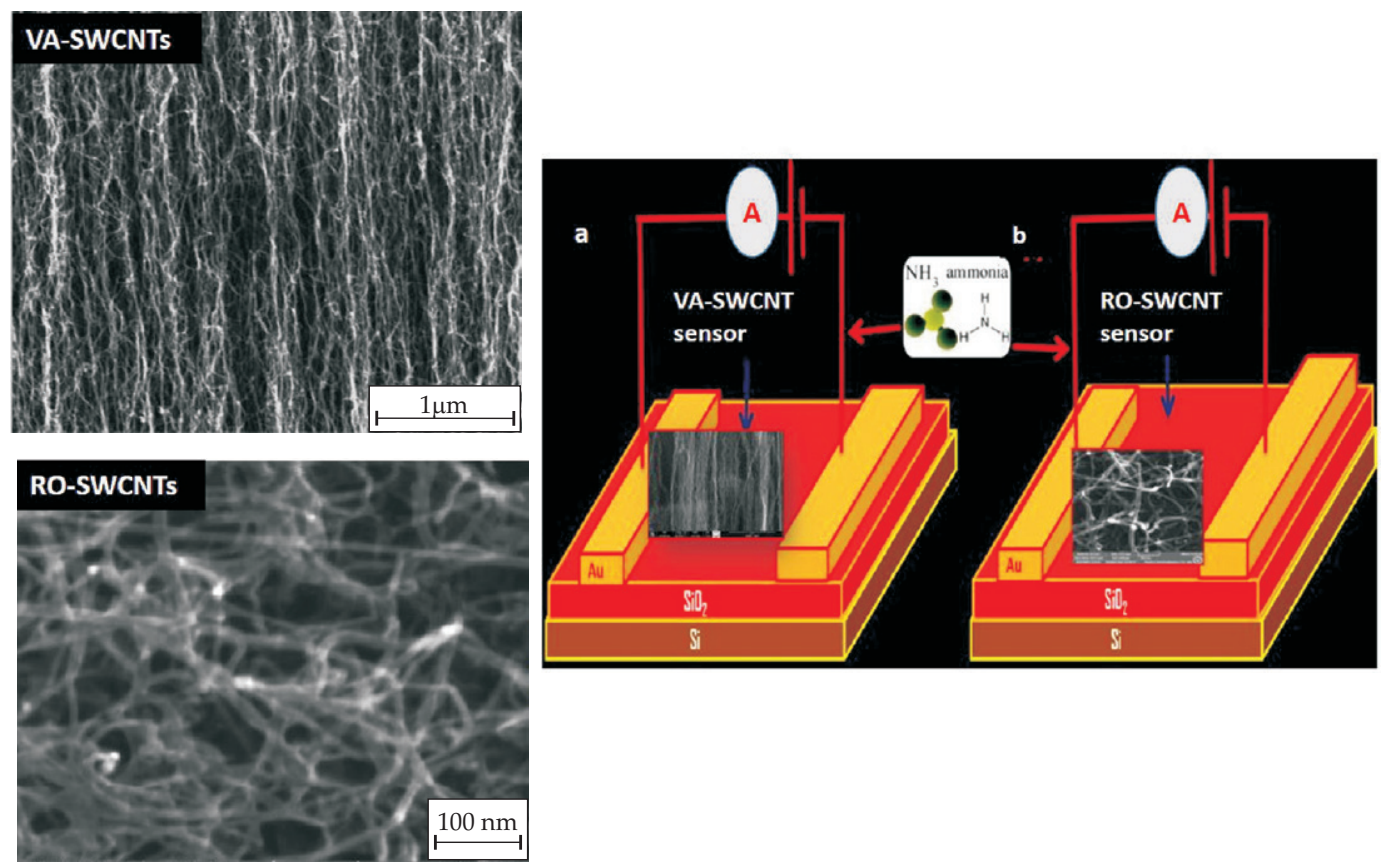

Fig. 7. a) VA-SWCNTs, b) RO-SWCNTs sensor; reproduce from ref. [78], Materials Research Bulletin

bricks has been developed by Lee et al. (2019) [77]. The nanocomposite materials of stoichiometric $\mathrm{WO}_{3}$ nanobricks and commercial CNTs with different contents (0.5, 1.0 and $1.5 \mathrm{wt} \%$ ) were simply fabricated by dispersing precursors in dimethylformamide (DMF). Their finding shows that all nanocomposite sensors exhibited p-type response to $\mathrm{NH}_{3}$ at low temperatures, and showed the synergistic enhancement of response in comparison with CNT-based sensors, and they were more stable than $\mathrm{WO}_{3}$ nanobricks-based sensors. At $50^{\circ} \mathrm{C}$, the $0.5 \mathrm{wt} \% \mathrm{CNT}$ -based sensor showed shorter recovery time, the $1.5 \mathrm{wt} \%$ CNT sensor showed a higher response and the $1.0 \mathrm{wt} \%$ CNT sensor demonstrated both shorter recovery time and higher response in comparison with CNT-based sensors. The synergistic enhancement of $\mathrm{NH}_{3}$-sensing properties in the nanocomposite sensor was attributed to the hole transfer through contacts between stoichiometric $\mathrm{WO}_{3}$ nanobricks and CNTs. At room temperature, the highest performance of the $1.0 \mathrm{wt} \%$ CNT-based sensor showed a good selectivity and good response to a low concentration of $\mathrm{NH}_{3}$. The calculated LOD (limit of detection) was $150 \mathrm{ppm}$, which showed a high potential of application in breath analysis. This results showed a very promising method to fabricate nanocomposite materials for gas sensors with low operational resistance, low power consumption and workable at room temperature [77].

The structural effect of SWCNTs grown by plasma enhanced chemical vapor deposition (PECVD) towards $\mathrm{NH}_{3}$ gas sensing has been studied [78]. The vertically aligned SWCNTs (VA-SWCNTs) and randomly oriented SWCNTs (RO-SWCNTs) have been successfully grown on silicon ( $\mathrm{Si}$ ) substrate and fabricated at an operating temperature of $650^{\circ} \mathrm{C}$ by PECVD technique. An excellent enhancement in sensor response about 200 to $250 \%$ was achieved by RO-SWCNTs sensor while for VA-SWCNTs sensor, it was 80 to $100 \%$ at constant concentration of $\mathrm{NH}_{3}$ (40 ppm) and at a temperature of $40^{\circ} \mathrm{C}$. Fast response/ recovery time characteristics with accurate repeatability and long term stability were observed in sensitivity. It was also observed that as-fabricated sensors are more selective towards $\mathrm{NH}_{3}$, compared to acetone $\left(\mathrm{C}_{3} \mathrm{H}_{6} \mathrm{O}\right)$, liquid petroleum gas (LPG) and methanol $\left(\mathrm{CH}_{3} \mathrm{OH}\right)$. The difference between the SWCNTs from the VA-SWCNTs and RO-SWCNTs fabricated sensors can be seen in Fig. 7. The findings found that from both set of sensors, excellent magnitude of sensor response ( 40 to $45 \%$ ) was observed on the exposure of $\mathrm{NH}_{3}$ at a constant concentration $10 \mathrm{ppm}$ and at an operating temperature of $40^{\circ} \mathrm{C}$. For other gases, the magnitude of sensor response was observed in between 5 to $15 \%$. The $\mathrm{NH}_{3}$ molecules start to adsorb on SWCNTs surface and the charge transfer from the adsorbed $\mathrm{NH}_{3}$ molecules to the SWCNTs surface contributes to the sensing signal. This indicates that a large charge transfer occurs when the SWCNT sensor surface gets interacted with $\mathrm{NH}_{3}$ molecules. An excellent RO-SWCNT sensor can be fabricated and it may be a step forward towards environmental monitoring and security purposes.

PANI/MWCNTs (PANI - polyaniline) nanocomposite was synthesized by in situ chemical oxidative polymerization of aniline monomers on MWCNTs-COOH [79]. Comparative gas sensing property analysis of the pristine MWCNTs-COOH and PANI/MWCNTs-COOH nanocomposite-based gas sensors revealed excellent 
sensor performance for PANI/MWCNTs-COOH nanocomposite-based sensor compared to MWCNTs-COOH at the concentration range of 2 to $10 \mathrm{ppm}$ of $\mathrm{NH}_{3}$. This is attributed to the presence of functional polyaniline on the surface of MWCNTs. Moreover, fast response and good reversibility were observed for the PANI/MWCNTs-COOH nanocomposite-based sensor compared to the pristine MWCNTs--COOH which can be mainly attributed to the enhanced charge transfer through the thick polymer layer on MWCNTs-COOH. The effects of humidity and oxygen $\left(\mathrm{O}_{2}\right)$ showed minimal interference on the sensor response. The PANI/MWCNTs-COOH nanocomposite was found to be highly selective towards $\mathrm{NH}_{3}$ gas compared to other gases; hydrogen sulfide $\left(\mathrm{H}_{2} \mathrm{~S}\right), \mathrm{C}_{3} \mathrm{H}_{6} \mathrm{O}$, isoprene $\left(\mathrm{C}_{5} \mathrm{H}_{8}\right)$, ethanol $\left(\mathrm{C}_{2} \mathrm{H}_{5} \mathrm{OH}\right)$, nitrogen dioxide $\left(\mathrm{NO}_{2}\right)$. The results show that, at $2 \mathrm{ppm}$ of $\mathrm{NH}_{3}$ the sensor response of $\mathrm{PANI} / \mathrm{MWCNTs}-\mathrm{COOH}$ is $15.5 \%$, while the pristine MWCNTs--COOH is $2.58 \%$. The response time and recovery time at $90 \%$ of total resistance change (T90) for PANI/MWCNTs-COOH and pristine MWCNTs-COOH are $6 \mathrm{~s}$ and $965 \mathrm{~s}$, and $35 \mathrm{~s}$ and $1440 \mathrm{~s}$, respectively.

A facile fabrication of PANI/MWCNTs/molybdenum disulfide ternary nanocomposite and its high-performance $\mathrm{NH}_{3}$ sensing at room temperature has been developed by Zhang et al. (2018) [80]. A high-performance $\mathrm{NH}_{3}$ sensor-based on PANI/MWCNTs/MoS nanocomposite results indicated that the sensor possesses not only high response, but also short response/recovery times, excellent repeatability and outstanding selectivity towards $\mathrm{NH}_{3}$ gas at room temperature. The probable $\mathrm{NH}_{3}$-sensing mechanism of the sensor was mainly ascribed to the synergistic influence of the ternary nanomaterials and distinct interactions at $\mathrm{p}-\mathrm{n}$ heterojunction [80].

Abdulla et al. (2015) [29] claimed that the fact that the performance of the PANI/MWCNTs-COOH was better compared to the pristine MWCNTs-COOH was due to two factors; (1) the excellent enhancement in the gas sensor performance of PANI/MWCNTs-COOH nanocomposite might originate from several factors. The enhanced sensing performance of PANI/MWCNTs- $\mathrm{COOH}$ nanocomposite can be related to the combined effect of doping/dedoping of PANI and the electron transfer between the $\mathrm{NH}_{3}$ molecules and MWCNTs-COOH. Polyaniline is a well-known conducting p-type semiconductor in its emeraldine salt form. $\mathrm{NH}_{3}$ molecules being electron donors act as dopants of PANI. When $\mathrm{NH}_{3}$ molecules were adsorbed on the surface of PANI, it reacted with $\mathrm{N}-\mathrm{H}$ groups of PANI forming $\mathrm{NH}_{4}^{+}$(ammonium ions) which led to the localization of polarons of PANI and thus increased the resistance of the sensor. During this reaction, polyaniline turned into emeraldine base form as shown at Eq. (4). The emeraldine salt form was recovered by desorption of adsorbed $\mathrm{NH}_{3}$ molecules by flushing with $\mathrm{N}_{2}$. During this reversible reaction, $\mathrm{NH}_{4}^{+}$ ions decomposed to $\mathrm{NH}_{3}$ and proton so that base resistance could be recovered and PANI became dedoped. The exposed MWCNTs-COOH in the composite also would interact with the electron donating $\mathrm{NH}_{3}$ molecules and could enhance the charge transfer between them by reducing the hole density in MWCNTs-COOH [29].

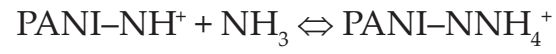

The second (2) factor could be the formation of uniformly covered PANI on the MWCNTs-COOH surface. The PANI layer on the peripheral walls of the MWCNTs- $\mathrm{COOH}$ might result in the formation of covalent bonds at the defect sites, subsequently leading to enhancement in their conductivity upon exposure towards gas molecules. In the case of pristine MWCNTs-COOH, $\mathrm{NH}_{3}$ molecules are strongly bound to the defect sites and generally it takes them several minutes to recover to its initial state under $\mathrm{N}_{2}$ flow. Figure 8 shows the selectivity of the PANI/MWCNTs-COOH nanocomposite, and schematic diagram of $\mathrm{NH}_{3}$ adsorption and electron transfer in the PANI/MWCNTs-COOH nanocomposite.

The nanocomposite of PPy (polypyrrole) and carboxylated multi-walled carbon nanotubes (MWCNTs-COOH) were synthesized by in situ chemical oxidative polymerization method using $\mathrm{HCl}$ as a dopant and ammonium persulfate (APS) as an oxidant and their sensor performance towards the $\mathrm{NH}_{3}$ detection at room temperature was studied [81]. The most sensitive PPy-MWCNTs$\mathrm{COOH}$ nanocomposites sensor to $\mathrm{NH}_{3}$ gas was obtained with 4 wt \% MWCNTs-COOH content and found to be stable in operation against the variation in operating temperature. The obtained response for PPy/MWCNTs- $\mathrm{COOH}$ sensor at operating temperatures such as $28^{\circ} \mathrm{C}$, $45^{\circ} \mathrm{C}, 55^{\circ} \mathrm{C}$ and $65^{\circ} \mathrm{C}$ at $2000 \mathrm{ppm}$ of $\mathrm{NH}_{3}$ concentration shows that the response of sensor is found to be decreased with increase in operating temperature. The selectivity of PPy/MWCNTs-COOH nanocomposite sensor was also tested for other gases such as LPG, $\mathrm{C}_{2} \mathrm{H}_{5} \mathrm{OH}, \mathrm{CH}_{3} \mathrm{OH}$, $\mathrm{C}_{3} \mathrm{H}_{6} \mathrm{O}$ and $\mathrm{CHCl}_{3}$ at the same concentration and the response is found to be highly selective towards $\mathrm{NH}_{3}$ among the other gases about $17 \%$ at 2000 ppm of $\mathrm{NH}_{3}$.

Fabrication of a sensor for selective detection of $\mathrm{NH}_{3}$ below 1 ppm is still a challenging task. However, the research done by Hussain et al. (2020) on $\mathrm{NH}_{3}$ sensing studies on PTh/MWCNTs (PTh - polythiophene) nanocomposites shows an interesting findings [41]. The sensor-based on PTh/MWCNTs-3 (PTh/MWCNTs nanocomposite containing 15\% MWCNTs to the weight of monomers) was found to be an ultra-sensitive (detection limit of $0.1 \mathrm{ppm}$ ), completely reversible, highly selective and stable $\mathrm{NH}_{3}$ sensor at room temperature. The sensing response of PTh/MWCNTs-3 at 2000, 1500, 1000, 500, 400, $200,100,50,1$ and $0.1 \mathrm{ppm}$ of $\mathrm{NH}_{3}$ was found to be $88.70 \%$, $73.27 \%$, 62.04\%, 51.65\%, 46.96\%, 42.97\%, 38.86\%, 35.18\%, $32.93 \%$ and $27.66 \%$, respectively. The result showed that the relative humidity had only a small effect on $\mathrm{NH}_{3}$ sensing properties of PTh/MWCNTs-3. The results show that the higher sensing response of PTh/MWCNTs nanocomposites-based sensors as compared to PTh may be due to 


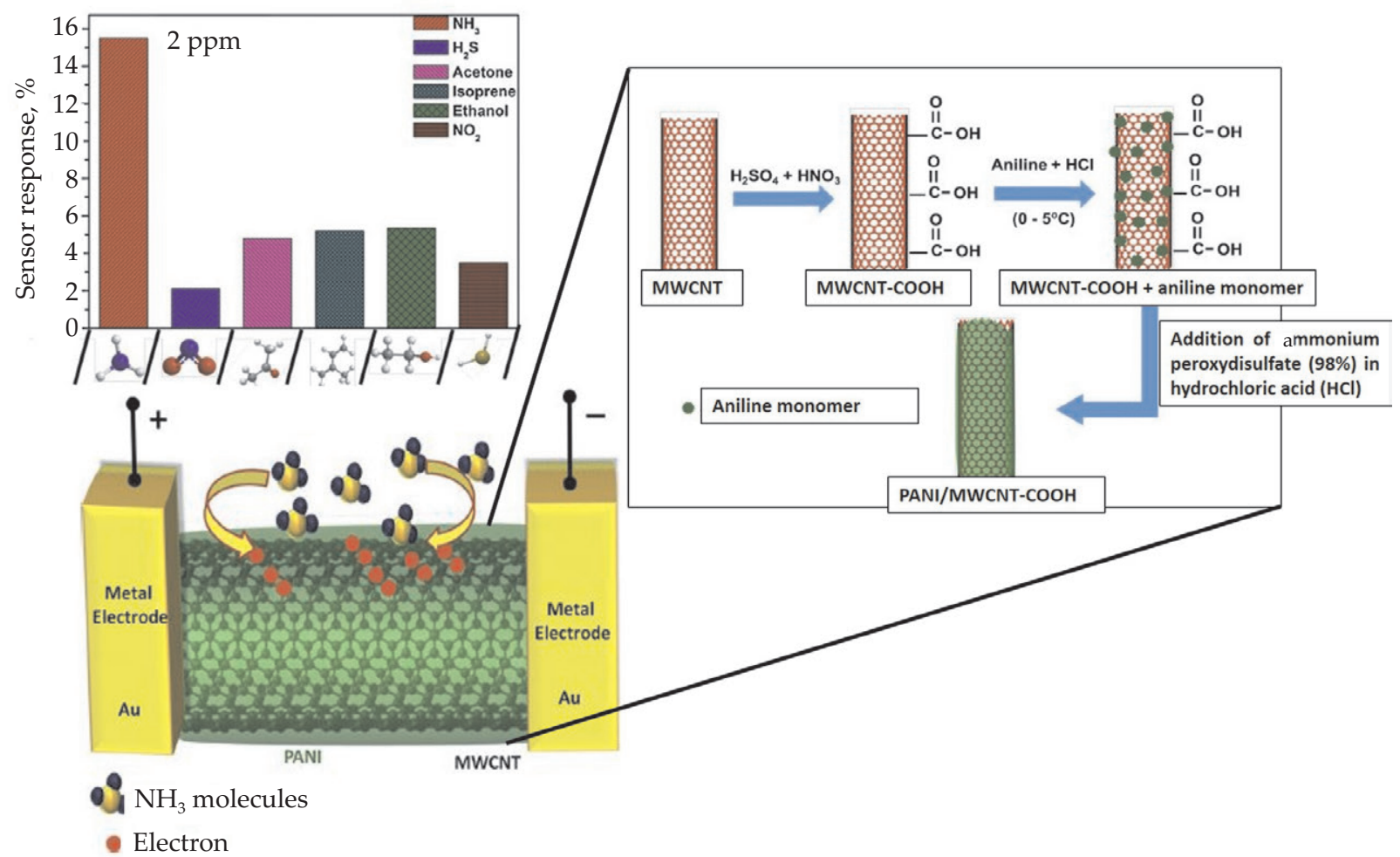

Fig. 8. Selectivity of the PANI/MWCNTs-COOH nanocomposite, and schematic diagram of $\mathrm{NH}_{3}$ adsorption and electron transfer in the PANI/MWCNTs-COOH nanocomposite; reproduce from ref. [29]

greater surface area as well as greater electrical conductivity. The greater surface area provides a large number of active sites for the adsorption of $\mathrm{NH}_{3}$ molecules. It is obvious that as the amount of MWCNTs increases, the surface area of PTh/MWCNTs nanocomposites also increases. Further study-based on PTh/MWCNTs-3 on its sensing response was calculated at several concentrations of $\mathrm{NH}_{3^{\prime}}$, ranging from $0.1 \mathrm{ppm}$ to $2000 \mathrm{ppm}$ was found to be $88.70 \%, 73.27 \%, 62.04 \%, 51.65 \%, 46.96 \%$, $42.97 \%, 38.86 \%, 35.18 \%, 32.93 \%$ and $27.66 \%$, respectively. At the higher concentrations, the greater number of $\mathrm{NH}_{3}$ molecules interacted with the huge number of polarons and neutralized them, which decreased the conductivity significantly. Hence at greater concentrations, the $\%$ sensing response (i.e. change in conductivity) was found to be greater. In opposition, at lower concentrations of $\mathrm{NH}_{3}$, a lesser \% sensing response was obtained, what was caused by the neutralization of a lesser number of polarons. Therefore, the highest and the lowest sensing responses were witnessed in $2000 \mathrm{ppm}$ and $0.1 \mathrm{ppm}$, respectively.

An ultra-sensitive, highly selective and completely reversible $\mathrm{NH}_{3}$ sensor-based on PTh/SWCNTs nanocomposite also has been reported by Husain and team [82]. The PTh/SWCNTs nanocomposite as a gas-sensor with extraordinary sensitivity and reproducibility at the room temperature $\left(27^{\circ} \mathrm{C}\right)$ was developed. Compared with pristine PTh, the sensitivity and the electrical conductivity of PTh/SWCNTs-3 was enhanced by incorporating SWCNTs, resulting in a lower detection limit of 5 ppm. PTh, PTh/SWCNTs-1, PTh/SWCNTs-2 and PTh/SWCNTs-3 showed initial conductivities of $5.734 \cdot 10^{-4}, 2.841 \cdot 10^{-4}, 4.668 \cdot 10^{-4}$, and $6.93715 \cdot 10^{-4} \mathrm{~S} / \mathrm{cm}$, respectively. The successful explanation of the sensing mechanism was-based on the association of polarons of PTh in an electronic interaction with lone pairs of $\mathrm{NH}_{3}$ during adsorption and desorption.

For the sensing mechanism, in PTh/SWCNTs-3, lone pairs of PTh interact with $\pi$-electrons of SWCNTs. As a result, hopping of polarons (charge carriers) takes place from the PTh to SWCNTs where they attain abrupt transferability along with the extended $\pi$-conjugated structure of SWCNTs. This leads to the electrical conductivity of PTh/SWCNTs-3 to rise significantly. The decrease and increase of DC electrical conductivity by the simple adsorption-desorption of ammonia vapors at room temperature $\left(27^{\circ} \mathrm{C}\right)$ was the basis of explaining the sensing mechanism of PTh/SWCNTs-3 as presented in Fig. 9. After exposure to $\mathrm{NH}_{3}$, the lone pairs of $\mathrm{NH}_{3}$ impede the mobility of polarons of PTh/SWCNTs-3 nanocomposite, resulting in a decline in the DC electrical conductivity. Once exposed in the ambient air, $\mathrm{NH}_{3}$ molecules desorbed from PTh/SWCNTs-3, and thus the DC electrical conductivity reverted to its original state. The mobility of polarons which causes loss and regain of DC electrical conductivity is considerably governed by the adsorption and desorption route of $\mathrm{NH}_{3}$ molecules on the vast surface of PTh/SWCNTs-3. 


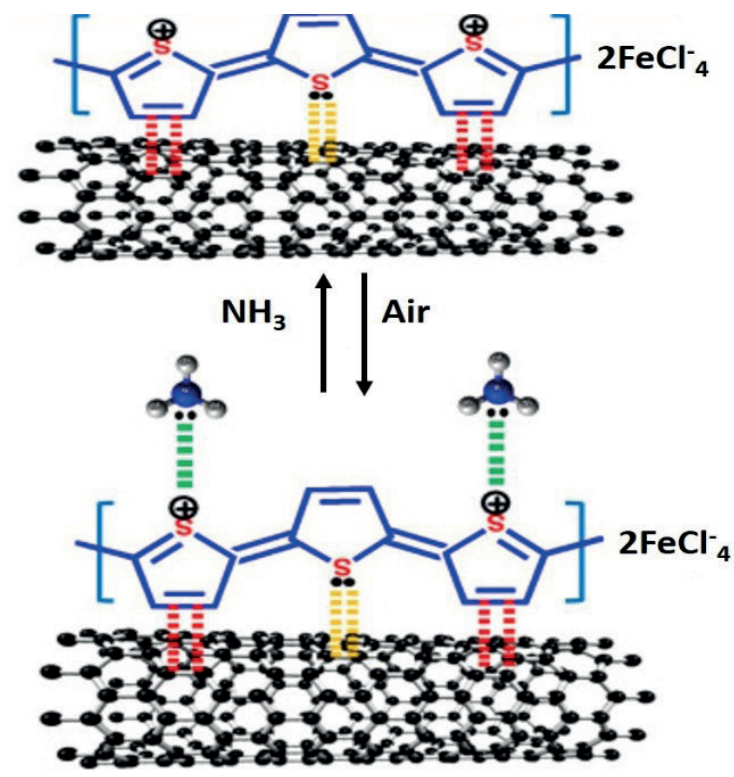

Fig. 9. The proposed mechanism of sensing interaction between $\mathrm{NH}_{3}$ gas with PTh/SWCNTs-3; adapted from ref. [82]

\section{CONCLUSIONS}

In recent decades, a number of novel sensor devices with respective methods for the detection of $\mathrm{NH}_{3}$ gas have been extensively investigated to alleviate the environmental and public health concerns. Solid state sensing techniques, including metal oxide and polymer-based sensors, have taken up a significant portion of $\mathrm{NH}_{3}$ gas sensor applications due to their outstanding advantages over other sensing techniques, such as simple and costeffective manufacturing and decent compatibility with other materials for synergistic effects in sensing. Mainly, metal oxide-based $\mathrm{NH}_{3}$ gas sensors have been intensely studied and widely applied because of their inherent high sensitivity towards the $\mathrm{NH}_{3}$ detection. Yet, a lot of efforts are still needed to improve their selectivity and sensitivity towards $\mathrm{NH}_{3}$ gas. Moreover, most metal oxide-based $\mathrm{NH}_{3}$ gas sensors require relatively high temperature, which is not promising in terms of energy efficient operation, portability, real-time detection, etc. Currently, one of advanced approaches to address these concerns is the incorporation with carbonaceous material, specifically, CNT to reduce the operation temperature due to its high electron mobility that is capable of improving the typical slow recovery rate of metal oxides greatly.

However, with regard to the room temperature operation, it still needs to be developed that lower desorption rate of analyte gases at room temperature and the high adsorption energy between analyte gas molecules and the active areas in sensing materials preclude the rapid recovery back to its initial state [83]. Similar to metal oxide-based $\mathrm{NH}_{3}$ gas sensors, conductive polymer-based $\mathrm{NH}_{3}$ gas sensors have also suffered from low selectivity resulting from humidity and swelling effects in conducting polymer sensing layers. In fact, humidity in air and swelling effect are merely minor drawbacks and the main shortcomings result from irreversibility and long-term instability, but the mechanism of irreversibility might be due to nucleophilic attack on carbon backbone [84]. Additionally, the long-term stability is hardly obtained due to the dedoping phenomenon in conductive polymers. Therefore, the improvement in the reversibility and long-term stability of conducting polymer-based $\mathrm{NH}_{3}$ gas sensors could be a future research orientation. To conclude, although a large number of studies in the past have mainly focused on the development of single sensing methods for the detection of $\mathrm{NH}_{3}$ gas, the hybridization of either sensing materials or detection methods has been accepted by most recent or advanced sensing techniques. As the field of novel hybridizations across sensing substances or detection techniques for accurate measurement of $\mathrm{NH}_{3}$ gas detection has grown rapidly, further research in fundamental studies for better understanding of sensing mechanisms, sensing properties, etc., sophisticated sensing systems is strongly designed to improve a guideline for improved sensing performance in $\mathrm{NH}_{3}$ gas detection. Moreover, since selectivity is the most challenging object for almost all types of $\mathrm{NH}_{3}$ gas sensors, it will also be necessary in the future to increase research efforts to improve selectivity in hybridized $\mathrm{NH}_{3}$ gas sensing systems.

\section{ACKNOWLEDGMENTS}

Financial support from Newton fund's Program and Malaysia Partnership and Alliances in Research (MyPAiR) for ISIS-NEWTON/2019/SG/01 and Chemical Defence Research Centre (CHEMDEF) for a research grant (UPNM/2018/ CHEMDEFF/ST/3) are gratefully acknowledged.

\section{REFERENCES}

[1] Rahman M.M., Alam M.M., Hussain M.M. et al.: Environmental Nanotechnology, Monitoring \& Management 2018, 10, 1. https://doi.org/10.1016/j.enmm.2018.04.001

[2] Sasmal M., Majumder S., Bhattacharyya T.K.: IEEE Sensors Journal 2018, 18 (20), 8223.

http://dx.doi.org/10.1109/JSEN.2018.2865123

[3] Rasyied A.R.Z. Mazlee N.N., Salim M.R. et al.: Journal of Telecommunication, Electronic and Computer Engineering 2018, 10 (1-3), 1.

http://umpir.ump.edu.my/id/eprint/20276

[4] Paolesse R., Nardis S., Monti D. et al.: Chemical Reviews 2017, 117 (4), 2517.

https://doi.org/10.1021/acs.chemrev.6b00361

[5] Cheng C.Y., Huang S.S., Yang C.M. et al.: Micromachines 2019, 10 (4), 276.

http://dx.doi.org/10.3390/mi10040276

[6] Xu R., Tian H., Pan S. et al:: Global Change Biology 2019, 25 (1), 314. https://doi.org/10.1111/gcb.14499

[7] Soliman M., Eldyasti A.: Reviews in Environmental Science and Bio/Technology 2018, 17 (2), 285. https://doi.org/10.1007/s11157-018-9463-4

[8] Cha J., Jo Y.S., Jeong H. et al.: Applied Energy 2018, 224, 194. https://doi.org/10.1016/j.apenergy.2018.04.100 
[9] Rouwenhorst K.H.R., Lefferts L.: Catalysts 2020, 10 (9), 999. http://dx.doi.org/10.3390/catal10090999

[10] Mordor Intelligence: Ammonia Market - Growth, Trends, and Forecast (2020-2025).

https://www.mordorintelligence.com/industry-reports/ ammonia-market (available 2020)

[11] Giddey S.P.S.B.S., Badwal S.P.S., Kulkarni A.: International Journal of Hydrogen Energy 2013, 38 (34), 14576.

https://doi.org/10.1016/j.ijhydene.2013.09.054

[12] Comotti M., Frigo S.: International Journal of Hydrogen Energy 2015, 40 (33), 10673. http://dx.doi.org/10.1016/j.ijhydene.2015.06.080

[13] Mani G.K., Rayappan J.B.B.: Sensors and Actuators B: Chemical 2013, 183, 459. https://doi.org/10.1016/j.snb.2013.03.132

[14] Kodu M., Berholts A., Kahro T. et al.: Beilstein Journal of Nanotechnology 2017, 8 (1), 571. http://dx.doi.org/10.3762/bjnano.8.61

[15] Qin Y., Zhang B., Zhang Z.: Organic Electronics 2019, 70, 240. http://dx.doi.org/10.1016/j.orgel.2019.04.023

[16] Bai S., Sun C., Yan H. et al.: Small 2015, 11 (43), 5807. http://dx.doi.org/10.1002/smll.201502169

[17] Chandrasekar M., Thiagamani S.M.K., Krishnasamy S. et al.: "Lightweight Polymer Composite Structures", CRC Press, 2020, pp. 309-330. http://dx.doi.org/10.1201/9780429244087-11

[18] Janudin N., Abdullah N., Yunus W.Md.Z.W. et al.: AIP Conference Proceedings 2019, 2068, 020061. https://doi.org/10.1063/1.5089360

[19] Janudin N., Abdullah N., Yaacob M.H. et al.: ZULFAQAR International Journal of Defence Science, Engineering \& Technology 2018, 1 (2), 76

[20] Janudin N., Abdullah N., Yaacob M.H. et al.: ZULFAQAR International Journal of Defence Science, Engineering \& Technology 2018, 1 (2), 65.

[21] Janudin N., Abdullah N., Yunus W.Md.Z.W. et al.: Journal of Nanotechnology 2018, 1, 1. http://dx.doi.org/10.1155/2018/2107898

[22] Mahajan C., Chaudhari P., Mishra S.: Journal of Materials Science: Materials in Electronics 2018, 29 (10), 8039. https://doi.org/10.1007/s10854-018-8810-0

[23] Peng N., Zhang Q.: "Sensing mechanisms of carbon nanotube-based $\mathrm{NH}_{3}$ gas detectors", in "Carbon Nanotubes", IntechOpen 2010. http://dx.doi.org/10.5772/39433

[24] Choi S.J., Lee S.J., Jang B.H. et al.: ACS Applied Materials \& Interfaces 2014, 6 (4), 2588. http://dx.doi.org/10.1021/am405088q

[25] Sireesha M., Babu V.J., Kiran A.S.K. et al.: Nanocomposites 2018, 4 (2), 36. https://doi.org/10.1080/20550324.2018.1478765

[26] He L., Jia J., Meng F. et al.: Materials Science and Engineering: B 2009, 163 (2), 76. https://doi.org/10.1016/j.mseb.2009.05.009

[27] Sharma A.K., Mahajan A., Bedi R.K. et al.: RSC Advances 2017, 7 (78), 49675.

https://doi.org/10.1039/C7RA08987B
[28] Huang L., Jiang P., Wang D. et al.: Sensors and Actuators B: Chemical 2014, 197, 308. https://doi.org/10.1016/j.snb.2014.02.081

[29] Sharma S., Hussain S., Singh S. et al.: Sensors and Actuators B: Chemical 2014, 194, 213.

https://doi.org/10.1016/j.snb.2013.12.050

[30] Dai H., Feng N., Li J. et al:: Sensors and Actuators B: Chemical 2019, 283, 786 .

https://doi.org/10.1016/j.snb.2018.12.056

[31] Qiu A., Li P., Yang Z. et al.: Advanced Functional Materials 2019, 29 (17), 1806306.

https://doi.org/10.1002/adfm.201806306

[32] Dai J., Ogbeide O., Macadam N. et al.: Chemical Society Reviews 2020, 49 (6), 1756. https://doi.org/10.1039/C9CS00459A

[33] Singh T., Bonne U.: "Gas Sensors" in "Reference Module in Materials Science and Materials Engineering", 1st ed., Elsevier, 2017.

[34] Abraham J.K., Philip B., Witchurch A. et al.: Smart Materials and Structures 2004, 13 (5), 1045.

https://doi.org/10.1088/0964-1726/13/5/010

[35] Donato N., Latino M., Neri G.: Carbon Nanotubes-from Research to Applications 2011, 14, 229.

http://dx.doi.org/10.5772/18855

[36] Miller D.R., Akbar S.A., Morris P.A.: Sensors and Actuators B: Chemical 2014, 204, 250.

https://doi.org/10.1016/j.snb.2014.07.074

[37] Rajesh, Ahuja T., Kumar D... Sensors and Actuators B: Chemical 2009, 136 (1), 275.

https://doi.org/10.1016/j.snb.2008.09.014

[38] Baharuddin A.A., Ang B.C., Haseeb A.S.M.A. et al.: Materials Science in Semiconductor Processing 2019, 103, 104616. https://doi.org/10.1016/j.mssp.2019.104616

[39] Hou L., Zhang C., Li L. et al.: Talanta 2018, 188, 41. http://dx.doi.org/10.1016/j.talanta.2018.05.059

[40] Jaisutti R., Lee M., Kim J. et al.: ACS Applied Materials \& Interfaces 2017, 9 (10), 8796

https://doi.org/10.1021/acsami.7b00673

[41] Husain A., Ahmad S., Mohammad F.: Materialia 2020, 14, 100868.

https://doi.org/10.1016/j.mtla.2020.100868

[42] Bak S.Y., Lee J., Kim Y. et al.: Sensors 2019, 19 (23), 5195. http://dx.doi.org/10.3390/s19235195

[43] Bindra P., Hazra A.: Sensors and Actuators B: Chemical 2019, 290,684 .

https://doi.org/10.1016/j.snb.2019.03.115

[44] Paoletti C., He M., Salvo P. et al.: RSC Advances 2018, 8 (10), 5578. https://doi.org/10.1039/C7RA13304A

[45] Xie L., Li Z., Sun L. et al.: Frontiers in Materials 2019, 6, 96. https://doi.org/10.3389/fmats.2019.00096

[46] Govindhan M., Sidhureddy B., Chen A.: ACS Applied Nano Materials 2018, 1 (11), 6005. https://doi.org/10.1021/acsanm.8b00835

[47] Alshammari A.S., Alenezi M.R., Lai K.T. et al.: Materials Letters 2017, 189, 299

https://doi.org/10.1016/j.matlet.2016.11.033 
[48] Zhang J., Wang S., Wang Y. et al.: Sensors and Actuators B: Chemical 2009, 139 (2), 411. https://doi.org/10.1016/j.snb.2009.03.014

[49] Tharsika T., Thanihaichelvan T., Haseeb A.S.M.A. et al.: Frontiers in Materials 2019, 6, 122. https://doi.org/10.3389/fmats.2019.00122

[50] Espid E., Adeli B., Taghipour F.: Journal of the Electrochemical Society 2019, 166 (5), H3223. https://doi.org/10.1149/2.0301905jes

[51] Zhang M., Chen H., Wang H.: Journal of The Electrochemical Society 2018, 165 (5), B167. https://doi.org/10.1149/2.0111805jes

[52] Li S., Lin P., Zhao L. et al.: Sensors and Actuators B: Chemical 2018, 259, 505. https://doi.org/10.1016/j.snb.2017.11.081

[53] Wang X.F., Ma W., Jiang F. et al.: Chemical Engineering Journal 2018, 338, 504. https://doi.org/10.1016/j.cej.2018.01.072

[54] Renganathan B., Sastikumar D., Gobi G. et al.: Optics \& Laser Technology 2011, 43 (8), 1398. https://doi.org/10.1016/j.optlastec.2011.04.008

[55] Chatterjee B., Bandyopadhyay A.: Environmental Quality Management 2016, 26 (1), 89. https://doi.org/10.1002/tqem.21483

[56] Wang C., Yin L., Zhang L. et al.: Sensors 2010, 10 (3), 2088. http://dx.doi.org/10.3390/s100302088

[57] Arafat M.M., Dinan B., Akbar S.A. et al.: Sensors 2012, 12 (6), 7207. http://dx.doi.org/10.3390/s120607207

[58] Rambu A.P., Ursu L., Iftimie N. et al.: Applied Surface Science 2013, 280, 598 . https://doi.org/10.1016/j.apsusc.2013.05.033

[59] Chang Y.W., Oh J.S., Yoo S.H. et al.: Nanotechnology 2007, 18 (43), 435504. https://doi.org/10.1088/0957-4484/18/43/435504

[60] Li Y., Wang H., Cao X. et al.: Nanotechnology 2007, 19 (1), 015503. https://doi.org/10.1088/0957-4484/19/01/015503

[61] Hunter G.W., Akbar S., Bhansali S. et al.: Journal of The Electrochemical Society 2020, 167 (3), 037570. http://dx/doi.org/10.1149/1945-7111/ab729c

[62] Bhati V.S., Hojamberdiev M., Kumar M.: Energy Reports 2020, 6,46 . https://doi.org/10.1016/j.egyr.2019.08.070

[63] Chimowa G., Tshabalala Z.P., Akande A.A. et al.: Sensors and Actuators B: Chemical 2017, 247, 11. https://doi.org/10.1016/j.snb.2017.02.167

[64] Young S.J., Lin Z.D.: Microsystem Technologies 2018, 24 (10), 4207. https://doi.org/10.1007/s00542-018-3712-x

[65] Pang Z., Yang Z., Chen Y. et al.: Colloids and Surfaces A: Physicochemical and Engineering Aspects 2016, 494, 248. http://dx.doi.org/10.1016/j.colsurfa.2016.01.024

[66] Liu I.P., Chang C.H., Huang Y.M. et al.: IEEE Journal of the Electron Devices Society 2019, 7, 476.
http://dx.doi.org/10.1109/JEDS.2019.2908419

[67] El-Sherbiny I.M., Hefnawy A., Salih E.: International Journal of Biological Macromolecules 2016, 86, 782.

http://10.1016/j.ijbiomac.2016.01.118

[68] Ahmad R., Tripathy N., Khan N.Y. et al.: RSC Advances 2016, 6 (60), 54836.

https://doi.org/10.1039/C6RA09731F

[69] Constantinoiu I., Miu D., Viespe C.: Journal of Sensors 2019, ID 8203810 . https://doi.org/10.1155/2019/8203810

[70] Nguyen D.M., Bui Q.B.: Journal of Electroanalytical Chemistry 2019, 832, 444 .

https://doi.org/10.1016/j.jelechem.2018.11.053

[71] Slobodian P., Riha P., Olejnik R. et al.: Carbon 2016, 110, 257. https://doi.org/10.1016/j.carbon.2016.09.023

[72] Zhou C., Zhao J., Ye J. et al.: Carbon 2016, 108, 372. https://doi.org/10.1016/j.carbon.2016.07.035

[73] Vidu R., Rahman M., Mahmoudi M. et al.: Frontiers in Systems Neuroscience 2014, 8, 91. http://dx.doi.org/10.3389/fnsys.2014.00091

[74] Al-Husseini A.H., Al-Sammarraie A., Saleh W.R.: Nano Hybrids and Composites 2018, 23, 8. https://doi.org/10.4028/www.scientific.net/NHC.23.8

[75] Isa S.S.M., Ramli M.M., Jamlos M.F.: AIP Conference Proceedings 2017, 1808, 020030. http://dx.doi.org/10.1063/1.4975263

[76] Neeru, Iha P., Chouksey A. et al.: AIP Conference Proceedings 2020, 2276, 020045. https://doi.org/10.1063/5.0025732

[77] Le X.V., Luu T.L.A., Nguyen H.L. et al.: Vacuum 2019, 168, 108861. https://doi.org/10.1016/j.vacuum.2019.108861

[78] Lone M.Y., Kumar A., Ansari N. et al.: Materials Research Bulletin 2019, 119, 110532. https://doi.org/10.1016/j.materresbull.2019.110532

[79] Abdulla S., Mathew T.L., Pullithadathil B.: Sensors and Actuators B: Chemical 2015, 221, 1523. https://doi.org/10.1016/j.snb.2015.08.002

[80] Zhang D., Wu Z., Li P. et al.:. Sensors and Actuators B: Chemical 2018, 258, 895. http://dx.doi.org/10.1016/j.snb.2017.11.168

[81] Bachhav S.G., Patil D.R.: Journal of Materials Science and Chemical Engineering 2015, 3 (10), 30. http://dx.doi.org/10.4236/msce.2015.310005

[82] Husain A., Ahmad S., Shariq M.U. et al.: Materialia 2020, 10, 100704. https://doi.org/10.1016/j.mtla.2020.100704

[83] Kwak D., Lei Y., Maric R.: Talanta 2019, 204, 713. https://doi.org/10.1016/j.talanta.2019.06.034

[84] Kemp N.T., Kaiser A.B., Trodahl H.J. et al.: Journal of Polymer Science Part B: Polymer Physics 2006, 44 (9), 1331. https://doi.org/10.1002/polb.20792

Received 17 XI 2020. 